"Do trust and corporate social responsibility activities affect purchase intentions? An examination using structural equation modeling"

\begin{tabular}{|c|c|}
\hline \multirow{3}{*}{ AUTHORS } & Imran Ali (D https://orcid.org/0000-0002-4525-5096 \\
\hline & Mohammad Naushad (D https://orcid.org/0000-0003-4421-3422 \\
\hline & Sulphey M. M. (D https://orcid.org/0000-0001-6042-2123 \\
\hline ARTICLE INFO & $\begin{array}{l}\text { Imran Ali, Mohammad Naushad and Sulphey M. M. (2020). Do trust and } \\
\text { corporate social responsibility activities affect purchase intentions? An } \\
\text { examination using structural equation modeling. Innovative Marketing , 16(4), 62- } \\
\text { 73. doi:10.21511/im.16(4).2020.06 }\end{array}$ \\
\hline DOI & http://dx.doi.org/10.21511/im.16(4).2020.06 \\
\hline RELEASED ON & Tuesday, 15 December 2020 \\
\hline RECEIVED ON & Wednesday, 04 November 2020 \\
\hline ACCEPTED ON & Tuesday, 08 December 2020 \\
\hline & $(\mathrm{cc})$ EY \\
\hline LICENSE & $\begin{array}{l}\text { This work is licensed under a Creative Commons Attribution } 4.0 \text { International } \\
\text { License }\end{array}$ \\
\hline JOURNAL & "Innovative Marketing " \\
\hline ISSN PRINT & $1814-2427$ \\
\hline ISSN ONLINE & $1816-6326$ \\
\hline PUBLISHER & LLC “Consulting Publishing Company "Business Perspectives" \\
\hline FOUNDER & LLC "Consulting Publishing Company "Business Perspectives" \\
\hline $0^{0}$ & $\begin{array}{l}\Xi= \\
\Xi=\end{array}$ \\
\hline NUMBER OF REFERENCES & NUMBER OF FIGURES \\
\hline 69 & 4 \\
\hline
\end{tabular}

(c) The author(s) 2021. This publication is an open access article. 


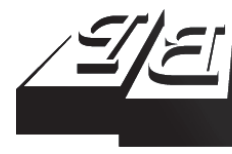

\section{BUSINESS PERSPECTIVES}

(2)

LLC "CPC "Business Perspectives"

Hryhorii Skovoroda lane, 10, Sumy, 40022, Ukraine

www.businessperspectives.org
Received on: $4^{\text {th }}$ of November, 2020 Accepted on: $8^{\text {th }}$ of December, 2020 Published on: $15^{\text {th }}$ of December, 2020

( Imran Ali, Mohammad Naushad, Sulphey M. M., 2020

Imran Ali, Assistant Professor, Noida Institute of Engineering and Technology (NIET), Greater Noida, India.

Mohammad Naushad, Ph.D., Assistant Professor, College of Business Administration, Prince Sattam Bin Abdulaziz University, Alkharj, Saudi Arabia. (Corresponding author)

Sulphey M. M., Ph.D., Professor, College of Business Administration, Prince Sattam Bin Abdulaziz University, Alkharj, Saudi Arabia.

\title{
DO TRUST AND CORPORATE SOCIAL RESPONSIBILITY ACTIVITIES AFFECT PURCHASE INTENTIONS? AN EXAMINATION USING STRUCTURAL EQUATION MODELING
}

\begin{abstract}
Organizations place great value on corporate social responsibility (CSR), as it has been found to influence customer attitudes and intentions. This study analyzed the impact of CSR on consumers' purchase intentions. The significance of this study arises from the fact that all progressive companies are increasing their expenditure on CSR activities. In this study, purchase intention was considered as a dependent variable, while trust, ethical, and legal CSR activities were the independent variables. Data for the study was collected from 210 randomly chosen respondents from amongst consumers of Delhi and National Capital Region of India. The data, analyzed using Structural Equation Modeling, found that trust, ethics, and legal CSR activities directly impacted consumer purchase intentions. These results indicate that legal factors do not significantly influence the corporate decision on spending on CSR activities. On the other hand, ethical factors and trust factors significantly influence the corporate decision on expenditure on CSR activities. The findings highlight companies' requirements to be conscious of their social image. Probable limitations of the study could include sample size and the number of variables chosen.
\end{abstract}

\section{Keywords}

JEL Classification

\section{INTRODUCTION}

Corporate social responsibility (CSR) has gained widespread attention in India since it became mandatory in April 2014 by amendment of the Companies Act. Companies are expected to involve in and contribute to the development of society. This has made companies enhance their expenditure in education, healthcare, training, women empowerment, and rural development (Poddar et al., 2019). CSR is also considered as an essential contributing factor for sustainable development (Kolk, 2016). CSR businesses can contribute to the growth, happiness, and prosperity of the society. CSR helps business organizations to differentiate themselves through generating competitive advantage (Peloza \& Shang, 2011). Competitive advantages would, in turn, create value for the company and its consumers. Such companies pay concerted attention to creating value for all their stakeholders. Consumers being the most important stakeholder, the value created for them is a strong determinant that trigger buying decisions (Xu et al., 2014). Multiple shreds of evidence exist to prove that consumers prefer companies that spend on CSR activities, be socially conscious, and engage in social development (Lee \& Lee, 2015; Parsa et al., 2015; 
Ramasamy \& Yeung, 2009). Perceived brand image and social acceptance are higher for socially responsive companies (Kim, 2019). Socially responsive organizations have been found to elicit positive responses and retention from consumers. This, in turn, has a direct impact on organizational profitability. However there are contrary views, also found in the literature. For instance, Fatma and Rahman (2016) found that consumers are more concerned about their economic benefits and are rarely influenced by the organization's social concern. They focus on personal services and will prefer to buy products that can satisfy them. Vaaland Terje I. et al. (2008) also found that customers do not consider CSR activities while making a purchase decision. Thus, there is a need to look into this aspect objectively.

Multiple studies about CSR have been done in the western world about the impact of CSR on consumer buying preferences, e.g. Salmones and Perez (2018), Grappi et al. (2013), He and Li (2011), Lacey and Kennett-Hensel (2010), and others. But very few examinations are done in India. However, scant literature exists regarding CSR's impact on consumer buying behavior (Bhattacharya et al., 2009). This paper intends to bridge this gap by addressing the question: "Do consumers prefer companies that spend more on the CSR activities"? Based on this, the study's main objective is to measure CSR activities' impact on consumer buying intention. The result of the study will facilitate in estimating the possibility of marketing returns from CSR expenditure.

\section{LITERATURE REVIEW AND HYPOTHESES}

Research interest in CSR has attracted widespread attention in recent days (Naushad \& Malik, 2015; Simionescu, 2015). Much attention from administrators, academicians, researchers, and managers has outlined its importance, if not indispensability. Corporates now use CSR to build brand equity and retain their customers (Kim, 2019; Reich et al., 2010). Governments also consider it essential for businesses to get involved in social issues (Carroll \& Shabana, 2010; Roitto, 2013). However, there is no universally accepted definition for CSR. It has been identified as voluntary efforts for society's development and growth (Kilcullen Maureen \& Ohles Kooistra Judith, 1999). These efforts are often remain and considered beyond state laws. Organizations often engage in CSR so that business and society can grow simultaneously (Kotler \& Lee, 2005). CSR can be considered to envisage all social and environmental dimensions into their business process and business strategy (Erkollar \& Oberer, 2012). Therefore, to structure the current problem and investigate the gap available in the literature, it is first necessary to underpin the theoretical background of the topics. The next subsections will explore the multiple subcomponents and their theoretical and practical relevance prevailed in the literature.

\subsection{Theoretical perspectives}

CSR can be discussed from the Stakeholder Theory and Normative Stakeholder Theory perspective. Both the theories address the cardinal question that managers need to ask themselves - To whom am I responsible? Further, both theories are built on the proposition that different stakeholders have varying needs. Stakeholder Theory focuses on the ethicality of the CSR initiatives. According to this, managers need to recognize and deal with a broad section of stakeholders (Aguinis, 2011). According to Smith (2003), this theory is based on the precinct that businesses need to give due consideration to the effects of their activities, without exception to all aspects of all stakeholders. The focus of Normative Stakeholder Theory is on ethics. The theory proposes that businesses need to be accountable morally to address all their stakeholders (Davies, 2003). The theories pre-suppose that values are inevitable and explicitly form part of any business.

CSR is a double-edged sword that simultaneously safeguards an organization from the community's negative impacts while maximizing the positive effects (Pinney, 2001). CSR has acquired importance as an effective business strategy (Luo \& Bhattacharya, 2006). Its utility is to help build a competitive position among peers, expand the business, and retain customers (Albus, 2012). CSR has also been found to increase financial performance and profitability. 
Therefore, business organizations are increasingly investing in CSR activities (EI-Garaihy et al., 2014; Ghosh \& Gurunathan, 2014).

Consumer attitudes towards CSR affect the buying decision. They are likely to have a lenient view and purchase from companies spending heavily on CSR activities (Ahmed et al., 2020; Galant \& Cadez, 2017; Mulaessa \& Wang, 2017; Servera-Francés \& PiquerasTomás, 2019). Voluntary activities under economic, legal, ethical, and philanthropic factors are traditionally known as CSR (Carroll, 1979). Consumers exhibit positive responses to organizations involved in CSR activities (Lee \& Lee, 2015; Parsa et al., 2015). CSR is likely to sustain organizations, even in volatile and challenging market situations. It can foster trust among consumers (Choi Beomjoon \& La Suna, 2013; Pérez Andrea \& Rodríguez del Bosque Ignacio, 2014). Based on these, the authors have identified ethics, legality, and trust as factors capable of influencing consumers' purchase decisions. This proposition is in line with Mulaessa and Wang (2017) and Nicolaides (2018). Next subsections investigate these variables by providing brief descriptions.

\subsection{Ethical CSR activities}

Though ethics and CSR have distinct characteristics, they are often considered the same (Dimitriades, 2007; Goel \& Ramanathan, 2014). Business ethics is a branch of applied ethics that examines moral or ethical problems that could arise from the business background (Stanwick \& Stanwick, 1998). Ethical CSR activities refer to the approach that an organization takes to treat its stakeholders. Organizations need to treat their stakeholders equally and fairly. Goel and Ramanathan (2014) studied CSR in the backdrop of Stakeholder Theory and proposed that it needs to be based on the paradigm of ethics and certain other dimensions. Ethics is the fulcrum around which the Normative stakeholder theory revolves. Drawing from the philosophy of ethics, Rodin (2005) states that businesses are morally bound to take care of a broad spectrum of stakeholder concerns.

Caroll (1979) considers CSR to encompass expectations associated with economic, legal, ethical, and philanthropic aspects. According to Nicolaides (2018), CSR is built on the edifice of ethical and legal philanthropic activities. All the internal operations and dealings with stakeholders, including employees, are ethical and responsible. Any unfair treatment of stakeholders needs to be avoided (Carroll, 1991). All material information needs to be disclosed to the customers in every transaction. Customers need to have product choices and must have the possibility of product comparison. Based on the review, it is hypothesized that "Ethical aspects have a positive relationship with the purchase intention."

\subsection{Legal CSR activities}

Companies must utilize available opportunities to grow and expand at a rapid pace. However, this needs to be within the framework of rules and regulations. Voluntary compliance with all laws and regulations of the land brings a positive image of the organization to the consumers. Business organizations need to comply with all laws of the land (Carroll, 1991). Consumers incline towards goods and services of organizations that comply with rules and regulations. CSR is a predisposition on the organization's part to continue its activities beyond mere legal obligations (Servera-Francés \& Arteaga-Moreno, 2015).

Compliance with all rules and regulations, and beyond them, positively impacts consumers' minds and directly impacts purchase intentions (Lee \& Lee, 2015). Organizations pursuing economic goals based on the local legal framework will positively influence consumers and society (Lee \& Lee, 2015; Mulaessa \& Wang, 2017). Firms sensitive to the laws and fair in business transmits are a positive message to the consumers. This influences the firm's image and the resultant purchase intention of consumers. In general, the legal aspects of CSR positively affect purchase intentions. Based on these, it is hypothesized that "Legal aspects have a positive relationship with the purchase intention."

\subsection{Trust}

Trust is an essential factor that influences consumers (Oney et al., 2017). Organizations that command consumer trust can take on the turbulence in the markets, are effective and sustainable (Mulaessa \& Wang, 2017). Trusted organizations are more sustainable and compete effectively 
in the industry. Organizations need to build full trust with its consumers about their products, services, and compliance and acquiescence with the land laws. Substantial evidence shows that CSR positively affects the corporate reputation and image, influencing consumer trust (Barcelos et al., 2015; Choi Beomjoon \& La Suna, 2013; Oney et al., 2017; Servera-Francés \& Arteaga-Moreno, 2015). Consumers prefer to buy from organizations that have developed trust as a result of having healthy CSR activities

Trust exists "...when one of the parties in exchange is aware of the reliability and integrity of other party" (Morgan \& Hunt, 1994). Trust is something that is based on consumers' beliefs, feelings, and expectations towards the organization. It relies on how far the organization provides importance to CSR. CSR activities can improve organizational reputation and image (Pérez Andrea \& Rodríguez del Bosque Ignacio, 2014). The highly positive impact of CSR on trust, despite service failure and subsequent recovery, has been observed by Choi and $\mathrm{La}$ (2013). Based on these, it is hypothesized that "Trust has a positive relationship with the purchase intention."

\subsection{Purchase intention}

Purchase intention indicates the desire of an individual to purchase a product. Several factors can affect the intent to buy a product. For instance, celebrity endorsement, advertising, sales promotion incentives, and service quality influence purchase intentions. Information quality plays a vital role in influencing consumer purchase intentions. The Internet has made it easier to search for information related to products. Thus, informed choices are now possible. Consumers develop positive feelings if CSR activities develop perceived value. The value generation could, in turn, increase consum- er loyalty (Gallarza \& Saura, 2006). CSR activities also enhance corporate reputation and loyalty, as well as facilitate retention (Galant \& Cadez, 2017).

Economic, legal and ethical CSR activities also influence consumers' intentions to purchase (Bae \& Kim, 2013; Lee \& Lee, 2015; Naushad, 2018; Uhlig et al., 2020). Companies spending on CSR activities are more competitive and can build an effective organization (David et al., 2005). It is in the organization's interest to maintain a positive attitude towards CSR activities because it impacts the consumer's purchase intention (David et al., 2005; Ramesh et al., 2019).

Therefore, in an attempt to testify the above discussion in the form of empirical evidence, the following research model can be proposed for this study (Figure 1).

Figure 1 provides the accumulative hypothesized model for this study. The study is interested in determining whether the factors emerged from literature and discussed in the above section (which include, ethical and legal CSR activities and trust) will help shape the purchase intention of the sample taken for the study. The following hypotheses can be framed:

$H_{1} \quad$ Ethical aspects have a positive relationship with the purchase intention.

$\mathrm{H}_{2} \quad$ Legal aspects have a positive relationship with the purchase intention.

$\mathrm{H}_{3} \quad$ Trust has a positive relationship with the purchase intention.

The next section discusses the methodology adopted to test the hypotheses.

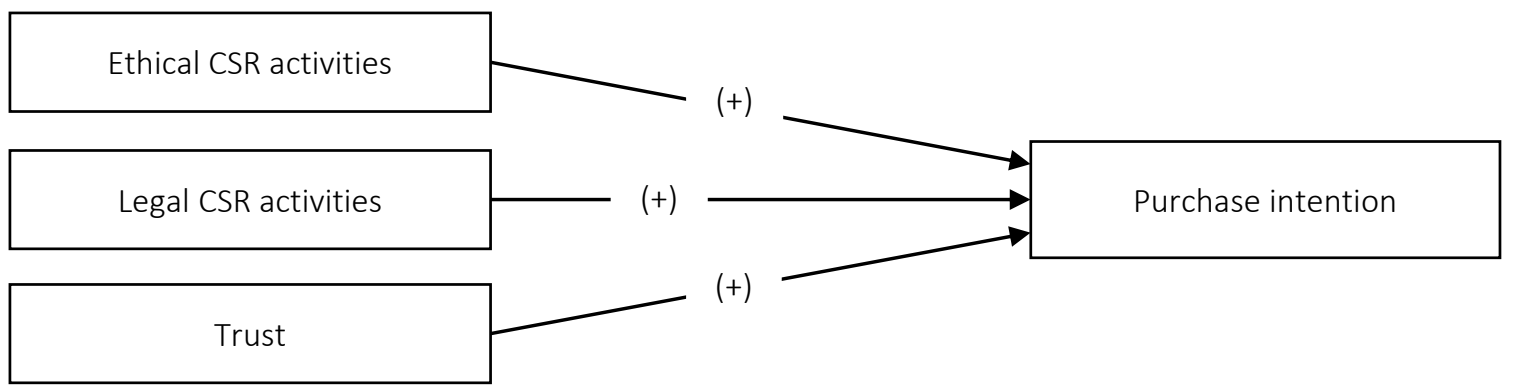

Figure 1. Research model 


\section{RESEARCH METHODOLOGY}

\subsection{Data collection instrument}

There are various instruments available in the literature to measure CSR. However, the measure developed by Sweeney and Soutar (2001) is widely accepted. This scale (also known as PERVAL) has three primary dimensions such as emotional, social, and functional. This study used this measure to collect data. The major factor to this choice is its acceptability and validity in the service environment. Moreover, this scale is validated widely in previous research (Gallarza et al., 2020; Ivanauskienè et al., 2012; Marin et al., 2009; Sandström et al., 2008; Sweeney \& Soutar, 2001; Walsh et al., 2014).

The questionnaire had a five-point Likert scale, ranging between Strongly agree and Strongly disagree. The questionnaire had two parts. The first part had the respondents' demographic profile, and the second had the study constructs. The questionnaire intends to receive accurate and relevant information from the respondents. The study constructs (Carroll, 1991) are:

1. Ethical CSR activities consisting of five items.

2. Trust with four items.

3. Legal CSR activities with three items.

4. Purchase intention with four items.

\subsection{Data collection and analytical tools}

Data was collected from a sample of 210 respondents via the Google survey form, Facebook, and Whatsapp. A convenience sampling method was adopted to collect data for the study. To analyze the data, statistical techniques, such as exploratory factor analysis (EFA), confirmatory factor analysis (CFA), and structural equation modeling (SEM), were used. EFA was used to determine the factors, and CFA was used to confirm the selected variables. SEM was used because it simultaneously checks all the study variables in the model (Chin, 1998).

\section{DATA ANALYSIS AND RESULTS}

IMB SPSS 23 and IBM AMOS 23 were used to analyze the data. Statistical Package for Social Sciences (SPSS) was used for the basic analysis. Exploratory factor analysis was used to reduce the number of items and determine the construct for the study. Further, confirmatory factor analysis was performed to analyze model fitness, composite reliability, average variance extracted, and discriminant analysis.

Table 1. Demographic profile

\begin{tabular}{|c|c|c|}
\hline Particulars & Frequency & Percentage \\
\hline \multicolumn{3}{|l|}{ Age } \\
\hline $20-25$ & 22 & 10.5 \\
\hline $25-30$ & 110 & 52.4 \\
\hline $30-35$ & 50 & 23.8 \\
\hline 35 and above & 28 & 13.3 \\
\hline Total & 210 & 100.0 \\
\hline \multicolumn{3}{|l|}{ Gender } \\
\hline Male & 110 & 52.4 \\
\hline Female & 100 & 47.6 \\
\hline Total & 210 & 100.0 \\
\hline \multicolumn{3}{|l|}{ Qualification } \\
\hline Undergraduate & 2 & 1.0 \\
\hline Graduate & 100 & 47.6 \\
\hline Post Graduate & 108 & 51.4 \\
\hline Total & 210 & 100.0 \\
\hline \multicolumn{3}{|c|}{ Monthly income (INR) } \\
\hline $0-25000$ & 80 & 38.1 \\
\hline $25,000-50,000$ & 66 & 31.4 \\
\hline $50,000-75,000$ & 48 & 22.9 \\
\hline $75,000-100,000$ & 16 & 7.6 \\
\hline Total & 210 & 100.0 \\
\hline
\end{tabular}

Construct validity refers to whether a construct is capable of measuring what it is supposed to measure. Construct validity consists of two components - convergent validity and discriminant validity. Convergent validity measures how close are the indicators variables to measuring a construct. Convergent validity value must be more than 0.50 to be acceptable. Table 2 shows that all the average variance extracted (AVE) values are greater than 0.50 . This indicates good convergent validity, as suggested by Fornell and Larcker (1981) and Hair et al. (1998). The composite reliability (CR) measures the internal consistency among the indicator variables of a particular construct. The $\mathrm{CR}$ values are above the rule of thumb (Hair et al., 2016). All four constructs thus enjoy composite reliability. 
Table 2. Construct validity and reliability

\begin{tabular}{|c|c|c|c|c|c|}
\hline Constructs & Item code & Items & Loading & AVE & CR \\
\hline \multirow{5}{*}{ Ethics } & Ethics1 & Company follows strict ethical code of conduct & 0.53 & \multirow{5}{*}{0.541} & \multirow{5}{*}{0.77} \\
\hline & Ethics2 & Company treats all the employees equally & 0.78 & & \\
\hline & Ethics3 & Company respects all cultures equally & 0.73 & & \\
\hline & Ethics5 & Company Adopts environment friendly practices & 0.56 & & \\
\hline & Ethics6 & Company promotes educational activities free of cost & 0.6 & & \\
\hline \multirow{4}{*}{ Trust } & Trust1 & Company makes credible promises & 0.55 & \multirow{4}{*}{0.66} & \multirow{4}{*}{0.76} \\
\hline & Trust2 & Company is honest with its staff & 0.81 & & \\
\hline & Trust3 & The company always keeps the promises it makes & 0.65 & & \\
\hline & Trust4 & If there is any problem, company supports me & 0.66 & & \\
\hline \multirow{3}{*}{ Legal } & LEg1 & $\begin{array}{l}\text { My company ensures that employees follow the organizational rules } \\
\text { and regulations }\end{array}$ & 0.28 & \multirow{3}{*}{0.54} & \multirow{3}{*}{0.61} \\
\hline & LEg2 & My company encourages formal and disciplined work culture & 0.67 & & \\
\hline & LEg3 & My company follows the principles defined by the regulatory system & 0.65 & & \\
\hline \multirow{4}{*}{$\begin{array}{l}\text { Purchase } \\
\text { intention }\end{array}$} & PI1 & I would buy new products of this company & 0.79 & \multirow{4}{*}{0.77} & \multirow{4}{*}{0.85} \\
\hline & $\mathrm{PI} 2$ & I would recommend products this company to others & 0.78 & & \\
\hline & $\mathrm{PI3}$ & I would buy products of this company continuously & 0.75 & & \\
\hline & $\mathrm{PI} 4$ & I am satisfied with the products and would prefer to buy in future & 0.76 & & \\
\hline
\end{tabular}

\subsection{Discriminant validity}

Discriminant validity shows how different are the latent variables from other constructs in the model (Hair et al., 2016; Hulland, 1999). Discriminant validity is assessed by comparing the AVE's square root with correlations of the latent variables (Fornell \& Larcker, 1981). The AVE's squared roots have to be higher than the $r$-values of other constructs (Hair et al., 2016). It can be seen from Table 3 that $r$-value is higher than the square roots of AVE (Fornell \& Larcker, 1981). This shows that the rule of thumb for discriminant validity is met (Fornell \& Larcker, 1981; Hair et al., 2016).

Table 3. Discriminant validity

\begin{tabular}{l|c:c:c|c}
\hline \multicolumn{1}{c|}{ Constructs } & Trust & LEg & Ethic & $\begin{array}{c}\text { CSR } \\
\text { expenditure }\end{array}$ \\
\hline Trust & 0.812 & & & \\
\hline Legal & 0.266 & 0.735 & & \\
\hline Ethic & 0.444 & 0.317 & 0.647 & \\
\hline Purchase intention & 0.334 & 0.224 & 0.334 & 0.878 \\
\hline
\end{tabular}

Confirmatory factor analysis was used to measure the reliability and validity of the questionnaire for this study. Confirmatory factor analysis was also used to test the fitness of the study model. The CFA model consisted of four constructs and 16 items. The model was tested and desired values were achieved. CMIN/DF value achieved is 3.802 , which must be between 2.00 and 5.00 for the good fit. GFI value achieved is .831, which must be around 0.90 for the good fit. AGFI value achieved is .831, which must be around 0.90 for the good fit. CFI value achieved is .779, which must be around 0.90 for the good fit. NFI achieved value is .727 , which must be around 0.90 for the good fit. The model for this study is fit on all the parameters that are considered important by the researchers. Therefore, overall model is adequately fit against the set values.

Table 4. Hypotheses testing

\begin{tabular}{c:c:c:c:c}
\hline Particulars & Estimate & S.E. & C.R. & P \\
\hline Purchase intention $\leftarrow$ Legal & 0.113 & 0.071 & 1.598 & 0.110 \\
\hdashline Purchase intention $\leftarrow$ Ethics & 0.213 & 0.065 & 3.257 & 0.001 \\
\hdashline Purchase intention $\leftarrow$ Trust & 0.254 & 0.074 & 3.416 & 0.000 \\
\hline
\end{tabular}

It is evident from Table 4 that legal factors do not significantly influence the corporate decision on expenditure on CSR activities because the $p$ value is 0.110 , which is more than .05 . Therefore, null hypothesis is accepted. On the other hand, ethical factors significantly influence the corporate decision for expenditure on CSR activities because $p$ value is 0.001 , which is less than .05 . Therefore, null hypothesis is rejected. Furthermore, Trust factors also significantly affect the corporate decisions for expenditure on CSR activities because $p$ value is 0.000 , which is less than .05 , therefore, null hypothesis is rejected. 


\section{DISCUSSION}

CSR is an essential business strategy for business organizations. Companies are trying to position themselves as socially responsible organizations (Bhattacharya et al., 2009; Glavas \& Godwin, 2013). They are spending heavily on social and environmental dimensions (Yadava \& Sinha, 2016). Companies have realized that businesses will only grow when the society is prosperous, and people have the money to spend on the goods and services produced by the business organizations. Sustainable development is important for both organization and society. Companies take resources from the society in the raw material and other resources. Therefore, companies should give back to the society as well.

The Government of India obliged companies with a certain turnover and profitability to spend two percent of their profit. According to the Companies Act 2013 , organizations with net worth of INR 500 or more or a turnover of INR 100 or more or net profit of INR 5 or more during any financial transaction must formulate a corporate social responsibility committee. CSR committee has to see whether Organization's CSR spending is in accordance with the law. This has revolutionized corporate spending in CSR activities. Companies mainly spend on education, employee training, health care and professional development in India. Education has been largely benefited by the organizations.

Nowadays, researchers investigate the influence of CSR activities on consumer buying behavior. This paper has taken ethical CSR, legal CSR and trust as independent variables and purchase intention as a dependent variable. Data analysis has outlined that ethical CSR activities influence the consumer purchase intention because every consumer prefers to purchase the products from companies that disclose all the information to their customers. Consumers can purchase quality products at low prices. Trust also influences the consumer's purchase intention. The hypothesis has proven that trust has a direct and positive impact on the consumer's purchase intention. Trust means that consumers are more likely to purchase from companies that they think are good and have good record of good business. The study findings are in tandem with earlier studies (Kim, 2019; Servera-Francés \& Piqueras-Tomás, 2019; Barcelos et al., 2015; Choi Beomjoon \& La Suna, 2013) etc.

CSR has a direct and positive impact on the consumer's purchase intentions (Mulaessa \& Wang, 2017; Lee \& Lee, 2015; Y. Xu et al., 2014; Bae \& Kim, 2013). CSR activities create a positive image in the minds of consumers and consumer feel that the company is taking good care of its stakeholders. Companies need to formulate appropriate business strategies to cater to the needs of society and business. Companies investing in CSR can build a strong business and brand image that will facilitate in distinguishing themselves.

This study has some limitations. It has considered only three independent variables. Future studies can include other variables and examine their impact on consumers' purchase intentions. Future research can also explore the impact of CSR on the marketing and business activities, apart from purchase intention. The study was undertaken with a sample of 210. Future research can be undertaken with a larger cross-sectional sample.

\section{CONCLUSION}

The study was undertaken to find the relationship of certain CSR variables with purchase intentions. Ethical CSR activities and trust are found to have a direct and positive impact on the consumer purchase intentions. The results of the study are of interest to both companies and consumers, since both of them show considerable interest in corporate social responsibility practices. CSR practices will help companies to gain competitive advantages and easily distinguish themselves from competitors. CSR practices are expected to have a direct and positive impact on both employee productivity and consumer purchase intentions. CSR practices require organizations to operate in a socially conscious manner, giving due importance to human rights, environmental concern and social concern. This study was a moderate attempt to clarify the relationship between CSR variables and purchase intentions. It is hoped that this study will motivate other researchers to use the results of the present work. 


\section{AUTHOR CONTRIBUTIONS}

Conceptualization: Imran Ali, Mohammad Naushad.

Data curation: Imran Ali.

Formal analysis: Imran Ali.

Investigation: Mohammad Naushad.

Methodology: Mohammad Naushad

Project administration: Sulphey M. M.

Resources: Mohammad Naushad.

Software: Sulphey M. M.

Supervision: Sulphey M. M.

Validation: Mohammad Naushad.

Visualization: Mohammad Naushad.

Writing - original draft: Imran Ali.

Writing - review \& editing: Mohammad Naushad, Sulphey M. M.

\section{REFERENCES}

1. Aguinis, H. (2011). Organizational responsibility: Doing good and doing well. In APA handbook of industrial and organizational psychology, Vol 3: Maintaining, expanding, and contracting the organization (Vol. 3, pp. 855879). American Psychological Association. Retrieved from https://www.researchgate.net/ publication/232592283_Organizational_responsibility_Doing_good_and_doing_well

2. Ahmed, I., Nazir, M. S., Ali, I., Nurunnabi, M., Khalid, A., \& Shaukat, M. Z. (2020). Investing In CSR Pays You Back in Many Ways! The Case of Perceptual, Attitudinal and Behavioral Outcomes of Customers. Sustainability, 12(3), 1158. Retrieved from https://econpapers.repec.org/ article/gamjsusta/v_3a12_ 3ay_3a2020_3ai_3a3_3ap_3a11583ad 3a317110.htm

3. Albus, H. (2012). The Effects Of Corporate Social Responsibility On Service Recovery Evaluations In Casual Dining Restaurants. Electronic Theses and Dissertations, 2004-2019. Retrieved from https:// stars.library.ucf.edu/cgi/viewcontent.cgi? article $=3177 \&$ context $=$ etd \&httpsredir $=1$ \&referer $=$

4. Bae, J., \& Kim, S. (2013). The influence of cultural aspects on public perception of the importance of CSR activity and purchase intention in Korea. Asian Journal of Communication, 23(1), 68-85. https://doi.org/10.10 80/01292986.2012.725174

5. Barcelos, E. M. B., de Paula Baptista, P., Maffezzolli, E. C. F., da Silva, W. V., Zancan, R., \& Marchetti, C. (2015). Relationship between an organization evaluated as being socially responsible and the satisfaction, trust and loyalty of its clients. Australian Journal of Basic and Applied Sciences, 9(7), 429-438. Retrieved from https://www.researchgate.net/ publication/277132360_Relationship_Between_an_Organization_ Evaluated_as_Being_Socially_Responsible_and_the_Satisfaction_ Trust_and_Loyalty_of_its_Clients

6. Bhattacharya, C. B., Korschun, D., \& Sen, S. (2009). Strengthening Stakeholder - Company Relationships Through Mutually Beneficial Corporate Social Responsibility Initiatives. Journal of Business Ethics, 85(2), 257-272. https://doi.org/10.1007/s10551008-9730-3

7. Carroll, A. B. (1979). A threedimensional conceptual model of corporate performance. Academy of Management Review, 4(4), 497-505. Retrieved from https://www.researchgate.net/ publication/230745468_A_ThreeDimensional_Conceptual_Model_ of Social_Performance
8. Carroll, A. B. (1991). Corporate social performance measurement: A commentary on methods for evaluating an elusive construct. Research in Corporate Social Performance and Policy, 12(42), 385-401. Retrieved from https:// www.researchgate.net/publication/287169147_Corporate_social_ performance_measurement_A_ comment_on_methods_for_evaluating_an_elusive_construct

9. Carroll, A. B., \& Shabana, K. M. (2010). The business case for corporate social responsibility: A review of concepts, research and practice. International Journal of Management Reviews, 12(1), 85-105. Retrieved from https:// www.researchgate.net/publication/287169147_Corporate_social_ performance_measurement_A_ comment_on_methods_for_evaluating_an_elusive_construct

10. Chin, W. W. (1998). Issues and opinion on structural equation modeling. MIS Quarterly, 22(1), vii-xv. https://www.jstor.org/ stable $/ 249674$ ?seq=1

11. Choi Beomjoon, \& La Suna. (2013). The impact of corporate social responsibility (CSR) and customer trust on the restoration of loyalty after service failure and recovery. Journal of Services Marketing, 27(3), 223-233. https://doi. org/10.1108/08876041311330717 
12. David, P., Kline, S., \& Dai, Y. (2005). Corporate social responsibility practices, corporate identity, and purchase intention: A dual-process model. Journal of Public Relations Research, 17(3), 291-313. https://doi.org/10.1207/ s1532754xjprr1703_4

13. Davies, R. (2003). Making globalization good: The moral challenges of global capitalism. In The business community: Social responsibility and corporate values (pp. 301-319.). Oxford University Press. Retrieved from https:// oxford.universitypressscholarship. com/view/10.1093/0199257019.00 1.0001/acprof-9780199257010

14. Dimitriades Zoe S. (2007). The influence of service climate and job involvement on customer-oriented organizational citizenship behavior in Greek service organizations: A survey. Employee Relations, 29(5), 469-491. https://doi. org/10.1108/01425450710776290

15. Erkollar, A., \& Oberer, B. (2012). Responsible business: The European Union is driving forward the European strategies on corporate social responsibility. Journal of EU Research in Business, 1. Retrieved from https://www.researchgate.net/ publication/266079185_Responsible_Business_The_European_ Union_is_Driving_Forward_the European_Strategies_on_Corporate_Social_Responsibility

16. Eweje Gabriel. (2014). Introduction: Trends in Corporate Social Responsibility and Sustainability in Emerging Economies. Corporate Social Responsibility and Sustainability: Emerging Trends in Developing Economies, 8, 3-17. Emerald Group Publishing Limited. https://doi.org/10.1108/S2043905920140000008001

17. Fatma, M., \& Rahman, Z. (2016). The CSR's influence on customer responses in Indian banking sector. Journal of Retailing and Consumer Services, 29, 49-57. https://doi.org/10.1016/j.jretconser.2015.11.008

18. Fornell, C., \& Larcker, D. F. (1981). Evaluating structural equation models with unobservable variables and measurement error. Journal of Marketing Research, 18(1), 39-50. Retrieved from https://www.jstor.org/ stable/3151312? seq $=1$

19. Galant, A., \& Cadez, S. (2017). Corporate social responsibility and financial performance relationship: A review of measurement approaches. Economic Research-Ekonomska Istraživanja, 30(1), 676-693. https://doi.org/10.1080/133167 7X.2017.1313122

20. Gallarza, M. G., \& Saura, I. G. (2006). Value dimensions, perceived value, satisfaction and loyalty: An investigation of university students' travel behaviour. Tourism Management, 27(3), 437-452. https://doi.org/10.1016/j.tourman.2004.12.002

21. Gallarza, M. G., Maubisson, L., \& Rivière, A. (2020). Replicating consumer value scales: A comparative study of EVS and PERVAL at a cultural heritage site. Journal of Business Research. https://doi.org/10.1016/j. jbusres.2020.01.070

22. Ghobadian, A., Gallear, D., \& Hopkins, M. (2007). TQM and CSR nexus. International Journal of Quality \& Reliability Management, 24(7), 704-721. https://doi. org/10.1108/02656710710774683

23. Glavas, A., \& Godwin, L. N. (2013). Is the perception of 'goodness' good enough? Exploring the relationship between perceived corporate social responsibility and employee organizational identification. Journal of Business Ethics, 114(1), 15-27. Retrieved from https://www.researchgate. net/publication/257541679_Is_ the_Perception_of_'Goodness'_ Good_Enough_Exploring_the_ Relationship_Between_Perceived_Corporate_Social_Responsibility_and_Employee_Organizational_Identification

24. Goel, M., \& Ramanathan, P. E. (2014). Business ethics and Corporate Social ResponsibilityIs there a dividing line. Procedia
Economics and Finance, 11(1), 49-59. https://doi.org/10.1016/ S2212-5671(14)00175-0

25. Grappi, S., Romani, S., \& Bagozzi, R. P. (2013). Consumer response to corporate irresponsible behavior: Moral emotions and virtues. Journal of Business Research, 66(10), 1814-1821. https://doi.org/10.1016/j. jbusres.2013.02.002

26. Hair, J. F., Black, W. C., Babin, B. J., Anderson, R. E., \& Tatham, R. L. (1998). Multivariate data analysis (Vol. 5, Issue 3). Prentice hall Upper Saddle River, NJ.

27. Hair, J. F., Sarstedt, M., Matthews, L. M., \& Ringle, C. M. (2016). Identifying and treating unobserved heterogeneity with FIMIX-PLS: part I - method. European Business Review. Retrieved from https://www.researchgate.net/ publication/281974244_Identifying_and_treating_unobserved_heterogeneity_with_FIMIX-PLS_part_I_-_method

28. He, H., \& Li, Y. (2011). CSR and service brand: The mediating effect of brand identification and moderating effect of service quality. Journal of Business Ethics, 100(4), 673-688. Retrieved from https://www.researchgate.net/ publication/227304178_CSR_ and_Service_Brand_The_Mediating_Effect_of_Brand_Identification_and_Moderating_Effect_of_ Service_Quality

29. Hulland, J. (1999). Use of partial least squares (PLS) in strategic management research: A review of four recent studies. Strategic Management Journal, 20(2), 195-204. https://www.jstor.org/ stable/3094025?seq $=1$

30. Ivanauskiene, N., Auruškevičienè, V., Škudienè, V., \& Nedzinskas, Š. (2012). Customer perceptions of value: Case of retail banking. Organizations and Markets in Emerging Economies, 3, 75-88. Retrieved from https://ideas.repec. org/a/vul/omefvu/v3y2012ilid127. html

31. Kilcullen Maureen, \& Ohles Kooistra Judith. (1999). At least do no harm: Sources on 
the changing role of business ethics and corporate social responsibility. Reference Services Review, 27(2), 158-178. https://doi. org/10.1108/00907329910275150

32. Kim, S. (2019). The Process Model of Corporate Social Responsibility (CSR) Communication: CSR Communication and its Relationship with Consumers' CSR Knowledge, Trust, and Corporate Reputation Perception. Journal of Business Ethics, 154(4), 1143-1159. https://doi. org/10.1007/s10551-017-3433-6

33. Kolk, A. (2016). The social responsibility of international business: From ethics and the environment to CSR and sustainable development. Journal of World Business, 51(1), 23 34. https://doi.org/10.1016/j. jwb.2015.08.010

34. Kotler, P., \& Lee, N. (2005). Best of breed: When it comes to gaining a market edge while supporting a social cause,"corporate social marketing" leads the pack. Social Marketing Quarterly, 11(3-4), 91103. Retrieved from https://www. scholars.northwestern.edu/en/ publications/best-of-breed-whenit-comes-to-gaining-a-marketedge-while-suppor

35. Lacey, R., \& Kennett-Hensel, P. A. (2010). Longitudinal effects of corporate social responsibility on customer relationships. Journal of Business Ethics, 97(4), 581-597. Retrieved from https://www.researchgate.net/ publication/226496464_Longitudinal_Effects_of_Corporate_ Social_Responsibility_on_Customer_Relationships

36. Lee, J., \& Lee, Y. (2015). The interactions of CSR, self-congruity and purchase intention among Chinese consumers. Australasian Marketing Journal (AMJ), 23(1), 19-26. https://doi.org/10.1016/j. ausmj.2015.01.003

37. Luo, X., \& Bhattacharya, C. B. (2006). Corporate social responsibility, customer satisfaction, and market value. Journal of Marketing, 70(4), 1-18. Retrieved from https://faculty. fuqua.duke.edu/ moorman/Mar-
keting-Strategy-Seminar-2015/ Session\%2012/Luo\%20and\%20 Bhattacharya\%202006.pdf

38. Marin, L., Ruiz, S., \& Rubio, A. (2009). The role of identity salience in the effects of corporate social responsibility on consumer behavior. Journal of Business Ethics, 84(1), 65-78. Retrieved from https://link.springer.com/article/10.1007/s10551-008-9673-8

39. Ministry of Corporate Affairs. (2013). The Companies Act 2013, section 135. Corporate Social Responsibility. Retrieved from https://www.mca.gov.in/SearchableActs/Section135.htm

40. Morgan, R. M., \& Hunt, S. D. (1994). The commitment-trust theory of relationship marketing. Journal of Marketing, 58(3), 20-38. Retrieved from https://www.jstor. org/stable/1252308?seq=1

41. Mulaessa, N., \& Wang, $H$. (2017). The effect of corporate social responsibility (CSR) activities on consumers purchase intention in China: Mediating role of consumer support for responsible business. International Journal of Marketing Studies, 9(1), 73-81. Retrieved from https://www.researchgate.net/ publication/312483156_The_Effect_of_Corporate_Social_Responsibility_CSR_Activities_on_ Consumers_Purchase_Intention_in_China_Mediating_Role_ of_Consumer_Support_for_Responsible_Business

42. Naushad, M. (2018). A study on the antecedents of entrepreneurial intentions among Saudi students. Entrepreneurship and Sustainability Issues, 5(3), 600617. Retrieved from https:// ideas.repec.org/a/ssi/jouesi/ v5y2018i3p600-617.html

43. Naushad, M., \& Malik, S. A. (2015). Corporate governance and bank performance: A study of selected banks in GCC region. Asian Social Science, 11(9), 226. Retrieved from http://www. ccsenet.org/journal/index.php/ass/ article/view/47164

44. Nicolaides, A. (2018). Corporate Social Responsibility as an Ethical Imperative. Athens Journal of Law,
4, 285-300. Retrieved from https:// www.researchgate.net/publication/328522309_Corporate_Social_Responsibility_as_an_Ethical_Imperative

45. Oney, E., Oksuzoglu Guven, G., \& Hussain Rizvi, W. (2017). The determinants of electronic payment systems usage from consumers' perspective. Economic Research-Ekonomska Istraživanja, 30(1), 394-415. https://doi.org/10. 1080/1331677X.2017.1305791

46. Parsa, H. G., Lord, K. R., Putrevu, S., \& Kreeger, J. (2015). Corporate social and environmental responsibility in services: Will consumers pay for it? Journal of Retailing and Consumer Services, 22, 250-260. https:// doi.org/10.1016/j.jretconser.2014.08.006

47. Peloza, J., \& Shang, J. (2011). How can corporate social responsibility activities create value for stakeholders? A systematic review. Journal of the Academy of Marketing Science, 39(1), 117-135. Retrieved from https://www.researchgate.net/ publication/225253801_How_ can_corporate_social_responsibility_activities_create_value_for_ stakeholders_A_systematic_review

48. Pérez Andrea, \& Rodríguez del Bosque Ignacio. (2014). Customer CSR expectations in the banking industry. International Journal of Bank Marketing, 32(3), 223-244. https://doi.org/10.1108/IJBM-092013-0095

49. Pinney, C. (2001). Imagine speaks out. How to manage corporate social responsibility and reputation in a global marketplace: The challenge for Canadian business. 23.

50. Poddar, A., Narula, S. A., \& Zutshi, A. (2019). A study of corporate social responsibility practices of the top Bombay Stock Exchange 500 companies in India and their alignment with the Sustainable Development Goals Corporate Social Responsibility and Environmental Management, 26(6), 1184-1205. https://doi. org/10.1002/csr.1741

51. Ramasamy, B., \& Yeung, $M$. (2009). Chinese Consumers' 
Perception of Corporate Social Responsibility (CSR). Journal of Business Ethics, 88(1), 119-132. https://doi.org/10.1007/s10551008-9825-x

52. Ramesh, K., Saha, R., Goswami, S., \& Dahiya, R. (2019). Consumer's response to CSR activities: Mediating role of brand image and brand attitude. Corporate Social Responsibility and Environmental Management, 26(2), 377-387. https://doi.org/10.1002/csr.1689

53. Reich, A. Z., Xu, Y. H., \& McCleary, K. W. (2010). The influence of social responsibility image relative to product and service quality on brand loyalty: An exploratory study of quickservice restaurants. Hospitality Review, 28(1), 2. Retrieved from https://www.semanticscholar. org/paper/The-influence-ofsocial-responsibility-image-toand-Reich-Xu/e07d4eda86aad67118b22ddda45fdd475eef6776

54. Rodin, D. (2005). The ownership model of business ethics. Metaphilosophy, 36(1-2), 163181. Retrieved from https:// www.researchgate.net/publication/227872125_The_ownership_ model_of_business_ethics

55. Roitto, A. (2013). Factors Effecting Corporate Social Responsibility Disclosure Ratings: An Empirical Study of Finnish Listed Companies. Oulu Business School, Oulu, Finlândia. Retrieved from http://jultika.oulu.fi/Record/nbnfioulu-201305201282

56. Salmones, M. M., \& Perez, A. (2018). Effectiveness of CSR advertising: The role of reputation, consumer attributions, and emotions. Corporate Social Responsibility and Environmental Management, 25(2), 194-208. https://doi.org/10.1002/csr.1453

57. Sandström, S., Edvardsson, B., Kristensson, P., \& Magnusson, P. (2008). Value in use through service experience. Managing Service Quality: An International Journal. Retrieved from https:// www.researchgate.net/publication/228363513_Value_in_use_ through_service_experience

58. Servera-Francés, D., \& ArteagaMoreno, F. (2015). The impact of corporate social responsibility on the customer commitment and trust in the retail sector. Ramon Llull Journal of Applied Ethics, 6, 161-178. Retrieved from https:// www.raco.cat/index.php/rljae/article/view/294904

59. Servera-Francés, D., \& PiquerasTomás, L. (2019). The effects of corporate social responsibility on consumer loyalty through consumer perceived value. Economic Research-Ekonomska Istraživanja, 32(1), 66-84. Retrieved from https://www. researchgate.net/publication/330571588_The_effects_of corporate_social_responsibility_ on_consumer_loyalty_through_ consumer_perceived_value

60. Simionescu, L. N. (2015). The relationship between corporate social responsibility (csr) and sustainable development (sd). Internal Auditing \& Risk Management, 10(2). Retrieved from https://ideas.repec.org/a/ath/ journl/v38y2015i1p179-190.html

61. Smith, N. C. (2003). Corporate social responsibility: Whether or how? California Management Review, 45(4), 52-76. https://doi. org/10.2307\%2F41166188

62. Stanwick, P. A., \& Stanwick, S. D. (1998). The relationship between corporate social performance, and organizational size, financial performance, and environmental performance: An empirical examination. Journal of Business Ethics, 17(2), 195-204. Retrieved from https://link.springer.com/article/10.1023/A:1005784421547

63. Sweeney, J. C., \& Soutar, G. N. (2001). Consumer perceived value: The development of a multiple item scale. Journal of Retailing, 77(2), 203-220. https://doi.org/10.1016/S00224359(01)00041-0

64. Tang, Z., Hull, C. E., \& Rothenberg, S. (2012). How corporate social responsibility engagement strategy moderates the CSR - financial performance relationship. Journal of Management Studies, 49(7), 12741303. https://doi.org/10.1111/ j.1467-6486.2012.01068.x
65. Uhlig, M. R. H., Mainardes, E. W., \& Nossa, V. (2020). Corporate social responsibility and consumer's relationship intention. Corporate Social Responsibility and Environmental Management, 27(1), 313-324. https://doi.org/10.1002/ csr. 1807

66. Vaaland Terje I., Heide Morten, \& Grønhaug Kjell. (2008). Corporate social responsibility: Investigating theory and research in the marketing context. European Journal of Marketing, 42(9/10), 927-953. https://doi. org/10.1108/03090560810891082

67. Walsh, G., Shiu, E., \& Hassan, L. M. (2014). Replicating, validating, and reducing the length of the consumer perceived value scale. Journal of Business Research, 67(3), 260-267. https://doi.org/10.1016/j. jbusres.2013.05.012

68. Xu, Y., Yu, W., \& He, Y. (2014) Research Review and Prospect of Corporate Social Responsibility and Consumers' Purchase Intention. In J. Xu, J. A. Fry, B. Lev, \& A. Hajiyev (Eds.), Proceedings of the Seventh International Conference on Management Science and Engineering Management (pp. 675-686). Springer Berlin Heidelberg. Retrieved from https://www. researchgate.net/publication/287263786_Research_review_ and_prospect_of_corporate_social_responsibility_and_consumers'_purchase_intention

69. Yadava, R. N., \& Sinha, B. (2016). Scoring sustainability reports using GRI 2011 guidelines for assessing environmental, economic, and social dimensions of leading public and private Indian companies. Journal of Business Ethics, 138(3), 549558. Retrieved from https://link springer.com/article/10.1007/ s10551-015-2597-1 


\section{APPENDIX A}

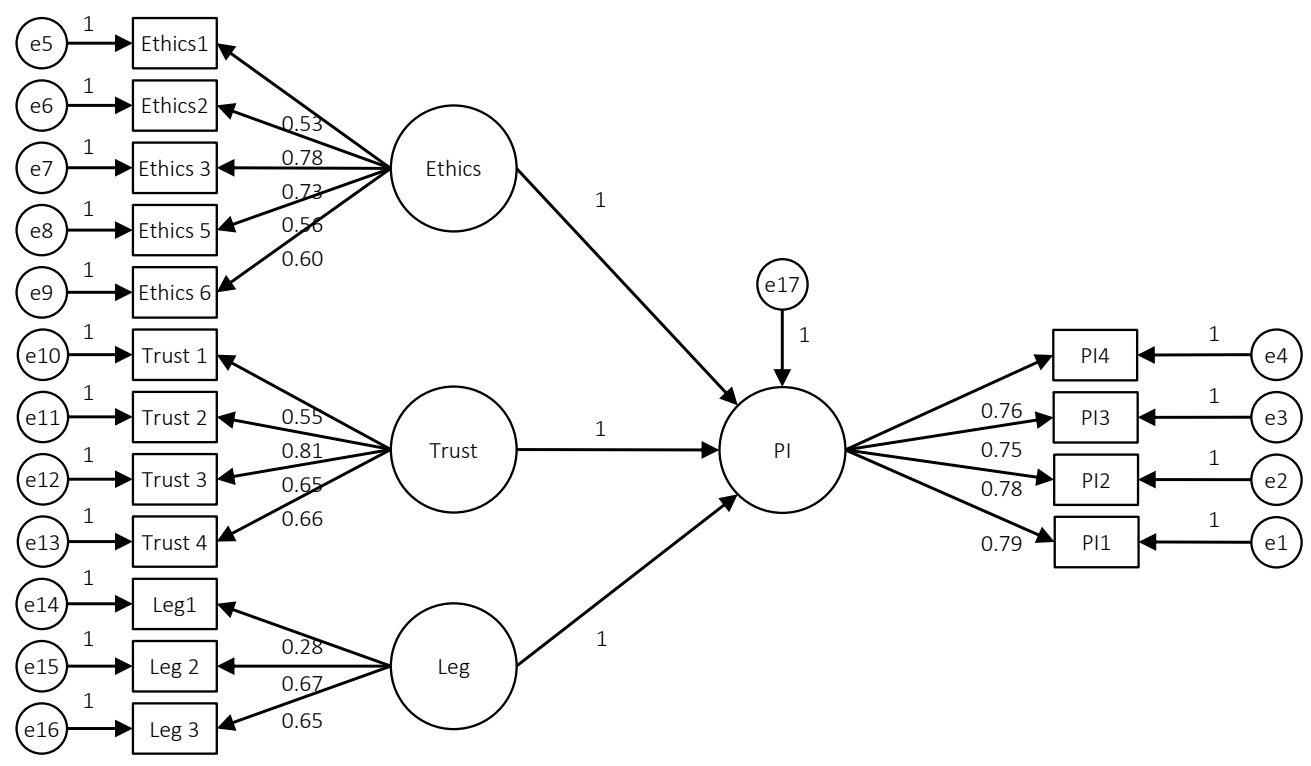

Figure A1. SEM output

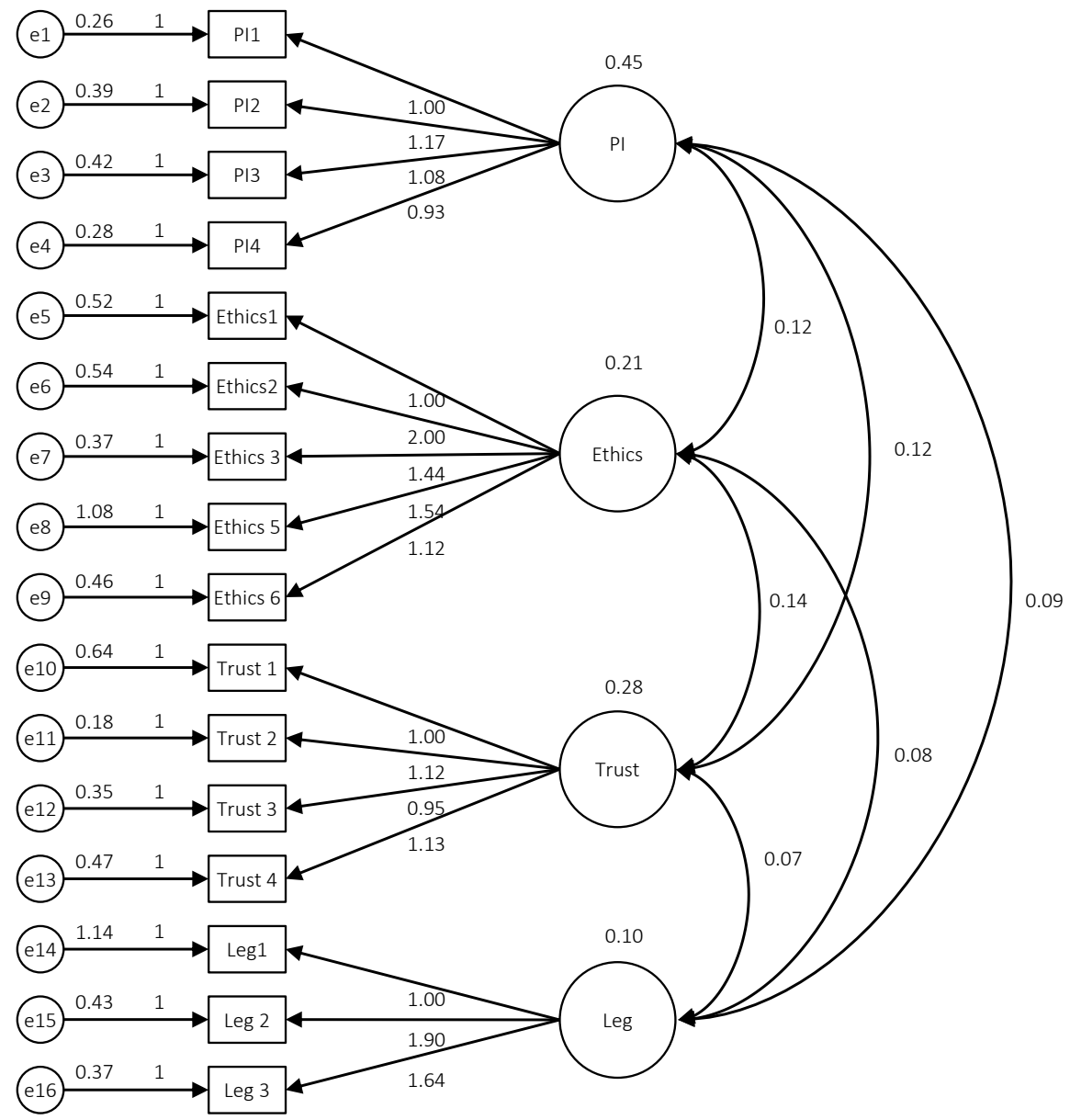

Figure A2. CFA output 